\title{
SENYVO AMŽIAUS ASMENU GRIUVIMAMS ITTAKOS TURINČIŲ FIZINIŲ, KOGNITYVINIŲ SAVYBIŲ RAIŠKA IR JŲ SĄSAJOS
}

\author{
Viktorija Piščalkiene் ${ }^{1}$, Jurgita Knašienè $\dot{e}^{1,3}$, Edgaras Lapinskas ${ }^{1}$, \\ Laura Rutkauskienè $\dot{1}^{1,4}$, Indrẻ Knyviené $\dot{2}^{2}$ \\ ${ }^{I}$ Kauno kolegijos Medicinos fakultetas, ${ }^{2}$ Kauno kolegijos Vadybos ir ekonomikos fakultetas, \\ ${ }^{3}$ Lietuvos sveikatos moksly universiteto Geriatrijos klinika, \\ ${ }^{4}$ Lietuvos sveikatos moksly universiteto Reabilitacijos klinika
}

Raktažodžiai: pagyvenę ir seni asmenys, statinès, dinaminès pusiausvyros vertinimas, griuvimai, kognityvinès veiklos vertinimas (MMSE), fizinis aktyvumas.

\begin{abstract}
Santrauka
Tyrimo tikslas - įvertinti senyvo amžiaus asmenų griuvimams ịtakią fizinių, kognityvinių savybių raišką ir jų sąsajas.

Tyrimo metodai: mokslinès literatūros analize; testavimai (plaštakos raumenu jègos matavimas, dinaminès pusiausvyros vertinimas „Stotis ir eiti“, statinès pusiausvyros vertinimas modifikuotu „Rombergo“" testu ir aparatu „Sigma Balance PAD“, kūno apimčių ir kūno masès matavimai, protinès veiklos vertinimas MMSE testu, apklausa žodžiu. Statistinè duomenų analizè atlikta naudojant SPSS 17 (aprašomoji statistika, vidurkių palyginimo $\mathrm{T}$ testas, Anova testas, koreliacinè analizè).

Tiriamieji. Tyrime dalyvavo 65 asmenys, kurių amžiaus vidurkis buvo 74,3 metai. Minimalus amžius - 60 metų, maksimalus - 86 metai. Tiriamieji pagal amžiaus grupes pasiskirstė: $60-74$ m. $-41,3 \%, 75$ ir daugiau m. $-58,7 \%$.

Rezultatai. Rombergo testo rezultatai tendencingai prastejja sudėtingejjant šios užduoties reikalavimams. Tiriamiesiems geriau sekèsi atlikti Rombergo testą atsimerkus nei užsimerkus. Užduoties „Atsistoti ir eiti“ atlikimo laiko vidurkis - 15,9 sek. Minimalios protinès veiklos testas (MMSE) parodé, kad daugiau nei 2/3 pagyvenusių ir senų asmenų pasižymi normaliomis kognityvinèmis funkcijomis, likusieji turi šių funkcijų mažesnių ar didesnių sutrikimų.

Vertinant rankų jègą standartiniu dinamometru nu-
\end{abstract}

statyta, kad dešinėje ir kairèje rankoje ji vidutiniškai siekè $24 \mathrm{~kg}$. Kairès rankos žasto apimtis $-31,9 \mathrm{~cm}$, dešinès $-32,5 \mathrm{~cm}$, kairès blauzdos apimtis $-38,3$ $\mathrm{cm}$, dešinès $-38,2 \mathrm{~cm}$. Statinè pusiausvyra buvo vertinama naudojant programini pusiausvyros aparatą "Sigma Balance PAD". Tačiau šiuo aparatu pusiausvyra buvo vertinama ne visiems, o tik tiems, kurie savarankiškai sugebejo išstovèti ant nestabilios platformos. Vaizdinio ilgis sieke $12,6 \mathrm{~cm}$, o vaizdinio plotas $0,46 \mathrm{~cm}^{2}$.

Nustatytas vidutinis, o kai kuriais atvejais ir stiprus statistinis ryšys tarp dešinès ir kairès rankos jegos, kuri buvo matuojama dinamometru ir statinès bei dinaminès pusiausvyros, blauzdų apimties ir net protinių funkcijų, tirtų MMSE. Vertinant statinę pusiausvyrą gauti statistiškai reikšmingi skirtumai, rodantys, kad pusiausvyos vertinimo metu pieštas vaizdnio ilgis yra susijęs su vaizdinio plotu (stiprus koreliacinis ryšys). Taip pat vaizdinio ilgis statistiškai reikšmingai susijęs su tiriamųjų blauzdų apimtimi (silpnas statistinis ryšys). Nustatyta, kad asmenys, kurie šiuo metu fiziškai aktyviai gyvena, pasižymi geresniais dinaminès pusiausvyros rodikliais ir gerenėmis protinėmis savybėmis Nepakankamos mitybos asmenys, kurių kūno masès indeksas (KMI) yra žemesnis nei norma, praščiau atliko MMSE. Šios išvados statistiškai reikšmingos $(\mathrm{p} \leq 0,05)$.

Tyrime dalyvavę asmenys, kurie per pastaraji pusmetị nepatyré griuvimų, pasižymi stipresne kairès bei dešinès rankos jëga $(\mathrm{p} \leq 0,05)$. Užduoti „Atsistoti ir eiti“" greičiau atliko griuvimu nepatyrusių asmenų grupe $(p \leq 0,05)$. Griuvimų nepatyrusių asmenų grupe pasižymi geresniais statinès pusiausvyros 
rodikliais $(\mathrm{p} \leq 0,05)$. Asmenys, kurie fiziškai yra aktyvesni (praktikuoja pasivaikščiojimą, darbą sode, darže ir pan.) rečiau patiria griuvimus $(\mathrm{p} \leq 0,05)$.

Fiziniai ir kognityvinių funkcijų rodikliai statistiškai reikšmingai skiriasi pagal amžių. Visi rodikliai yra prastesni 75 ir daugiau metų turinčių asmenų grupeje. Šios amžiaus grupès asmenys prasčiau atliko pusiausvyrą ir kognityvines funkcijas vertinančius testus. Tarp šių asmenų nustatytas mažesnis fizinio aktyvumo lygmuo, taip pat jie pasižymèjo prastesnèmis protinėmis savybėmis, vertintomis taikant MMSE $(\mathrm{p} \leq 0,05)$. Asmenys, kurie jaunysteje ir gyvenime buvo fiziškai aktyvūs, pasižymi geresniais fiziniais ir kognityviniais rodikliais $(\mathrm{p} \leq 0,05)$.

\section{Ivadas}

Remiantis Pasaulio sveikatos organizacija, „Sveikata tai fizinè, dvasinè ir socialinè gerové, o ne tik ligos ar negalios nebuvimas". Vis labiau senstanti visuomenè reikalauja didesnio sveikatos priežiūros sistemos dèmesio bei žinių apie šiai jautriai socialinei grupei kylančius sunkumus ir jų problemų sprendimo būdus. Biopsichosocialinio modelio požiūris ị senyvo amžiaus visuomenès dalị turètų apimti ne tik jau esamų ligų ar sveikatos sutrikimų sprendimo būdus, tačiau didžiaja dalimi visuomenès mokymą apie ligu profilaktiką, sveiką gyvenimo būdą ir reguliarų, kryptingą fizinį aktyvumą.

Raumenų masės rodiklis vaidina svarbų vaidmenį esant kritinèms sveikatos būklèms ir sunkioms traumoms. Raumenų jëga ir funkcija yra centriné figūra organizmo gijimo ir atsistatymo procese. Žmogaus funkcinio pajègumo sumažèjimo mastas ir trukmè, patyrus kritines sveikatos būkles - dramatiškas. Tyrimai rodo, jog mažiau kaip 50 procentų žmonių po kritinių sveikatos sutrikimų grịžta ị darbą anksčiau kaip metai po išrašymo iš ligoninès stacionaro [2].

Sarkopenija - tai laipsniškas raumenų masès netekimas ir funkcijos prastejimas, susijęs su žmogaus senėjimo procesu. Tai ypač paplitęs sindromas tarp senyvo amžiaus žmoniu ir yra vienas iš pagrindiniu gyvenimo kokybès ir gyvenimo trukmès trumpejimo faktoriu. Šis sindromas reikšmingai padidina tikimybę patirti griuvimus bei mažina senyvo amžiaus žmonių funkcinị aktyvumą kasdieninèje veikloje [9].

Didelis raumenų masės kiekio, jègos ir funkcijos praradimas po hospitalizavimo esant ūmioms sveikatos būklëms ilgam pablogina žmogaus fizinę sveikatą ir neigiamai prisideda prie užsitęsusio sveikimo periodo. Dél šios priežasties 50 procentų moterų, vyrsnių nei 65 metai, patyrusių šlaunikaulio kaklelio lūži griuvimo metu, niekada jau nebepradeda vèl vaikščioti [6].
Jungtinėse Amerikos Valstijose lètinès ligos, susijusios su prastu gyvenimo būdu, sudaro du trečdalius visų mirčių [1]. Dauguma atliekamų tyrimų sveikatos sutrikimų rizikos vertinimui remiasi mitybos ir fizinio aktyvumo bei kraujo lipidų, kūno masès indekso ir kaulų biomarkerių rodiklių rodmenimis. Tačiau labai mažai tyrimų, kurie nagrinètų sveikatos sutrikimų riziką vertinant raumenų masę, fizines ir metabolines funkcijas. Nepaisant to, raumenu fiziniai ir funkciniai rodikliai užima labai svarbų vaidmeni vystantis labiausiai paplitusioms ligoms ir sveikatos būklèms [24].

Mechaninè jèga, veikianti kaulus, atsirandanti fizinio aktyvumo metu susitraukinėjant raumenims, svarbus rodiklis modeliuojantis ir remodeliuojantis procesus, kurie didina kaulų stiprumą ir masę [11]. Pratimai, kurių metu naudojamas tik kūno svoris, sukelia tiesioginę mechaninę apkrovą kaulams, didžioji apkrovos dalis yra sukeliama raumens susitraukimo. Tiriant sveikus sportininkus [7] ir žmones, patyrusius galvos smegenų insultą [16], buvo nustatytas reikšmingas tiesioginis ryšys tarp plaštakos raumenų jẻgos ir plaštakos kaulų kaulinio audinio mineralų kiekio, mineralinio tankio. Autoriai padarė išvadą, jog yra reikšmingas ryšys tarp raumenų susitraukimo jègos, kaulų stiprumo ir masès.

Fiziniai pratimai gali atlikti svarbų vaidmenị kaip paprastas, nebrangus ir veiksmingas terapijos būdas, gydant depresiją, stresą ir padidejusį nerimą. Šie negalavimai yra taip pat priskiriami prie aktualių senėjančios visuomenès sveikatos priežiūros problemų [22].

Nemažai tyrimų atskleide, kad su amžiumi kinta fizinès žmogaus ypatybès, taip pat ir judesio stereotipas: didèja žingsnio plotas, pailgèja kojos pernešimo fazès laikas einant, sumažèja liemens sukamieji judesiai, atsiranda skausmas ir diskomfortas iprasto funkcinio aktyvumo metu. Skelton ir kt. [21] nustatè, kad fiziškai neaktyvūs vyresnio amžiaus žmonès pripranta prie atsargaus judejjimo „stiliaus“(trumpesnis žingsnio ilgis ir lètesnis žingsnio greitis), kas nèra būdinga senyvo amžiaus žmonèms, kurie yra fiziškai aktyvūs. Šie neadekvatūs kompensaciniai judejimo stereotipai mažina judesio variabilumą ir gali didinti tikimybę patirti traumą kintančioje asmens mobilumo aplinkoje.

Brooke ir kt. atliktas tyrimas su moterimis pomenopauziniu periodu atskleide tiesiogines sąsajas tarp fizinio aktyvumo ir fizinių ypatybių. Tokia pati išvada pateikiama ir Sernache de Freitasl ir kt. [20] atliktame tyrime, kuriame dalyvavo 77 moterys (60-75 metų amžiaus). Tiriamujų fizinis aktyvumas vertintas klausimynu, vertinta statine ir dinamine pusiausvyra testais bei pusiausvyra stovint ant posturografinès platformos. Išanalizavę gautus rezultatus, autoriai teigia, jog fizinis aktyvumas reikšmingai pagerina 
senyvo amžiaus žmonių pusiausvyrą [4].

Fizinis aktyvumas gali ne tik padidinti ir išsaugoti kaulu mineralinị tankị, bet ir apsaugoti nuo kritimų bei jų sukeltų kaulų lūžių. Raumenų silpnumas yra pagrindinis kritimų rizikos veiksnys, tačiau ne mažiau kaip 5 valandos fizinio aktyvumo per savaitę reikšmingai sumažina šlaunikaulio kaklelio lūžio riziką [23].

Fiziškai nepriklausomi vyresnio amžiaus žmonès su didesniu aerobiniu pajègumu turi geresnę pusiausvyrą bei aukštesni fizinio aktyvumo lygi kasdieniniame gyvenime [13]. Žmonès, kurie tapo fiziškai aktyvūs tik išèję i pensiją, turi ribotas galimybes tobulèti fiziškai, palyginti su tais, kurie buvo fiziškai aktyvūs nuolat. Tačiau anot Perrin ir kt. [17], nors ir pradejjus fiziškai aktyvų gyvenimo būdą tik senyvame amžiuje, tai suteikia daugiau pranašumo fiziniu lygmeniu, lyginant su tais, kurie sportavo savo 30-40 gyvenimo metais ir nutraukè reguliarų fizinį aktyvumą, ar su tais, kurie niekada nebuvo fiziškai aktyvūs.

Fizinis aktyvumas, kurio taikinys yra modifikuojamieji rizikos veiksniai ir neuroprotekcinių mechanizmų paleidimas smegenyse, gali sulètinti kognityvinių funkcijų blogèjimą, susijusị su normaliu senejjimo procesu bei apsaugoti nuo Alzheimerio ligos ir kitu demencijų atsiradimo. Fiziniai pratimai turi daugiakomponenti poveikị: padeda kontroliuoti kardiovaskulinius rizikos veiksnius, aktyvina neurotrofinius ir neuroplastinius procesus ịvairiose smegenų struktūrose [19]. Mažiausiai $150 \mathrm{~min}$. aerobinio fizinio aktyvumo per savaitę pagerina kognityvines funkcijas (vykdomąsias, dèmesị, darbinę atmintị, epizodinę atmintị, mąstymo greitị) [5].

Keletas studijų atskleide ne tik fizinio aktyvumo ir fizinių ypatybių lavejjimo sąsajas, bet ir tiesioginị ryši tarp fizinio aktyvumo ir teigiamo poveikio pagyvenusių žmonių kognityvinèms funkcijoms. Moterys su aukštesniais fizinio aktyvumo rodikliais turèjo ir aukštesnius kognityvinių funkcijų rezultatus, todèl Yaffe ir kt. [14] padare išvadas, jog žemas fizinio aktyvumo lygis gali būti traktuojamas kaip rizikos faktorius, bloginantis kognityvines funkcijas. Reguliarus fizinis aktyvumas gali apsaugoti pagyvenusius asmenis nuo kognityvinių funkcijų prastejjimo ir demencijos [15]. Ankstesnių autorių rezultatus patvirtina ir Gelder ir kt. [12] tyrime gauti rezultatai. Tyrimas, kuriame dalyvavo pagyvenę vyrai iš Suomijos, Italijos ir Olandijos, atskleide, jog asmenys, dalyvaujantys didelio, vidutinio ar net mažo intensyvumo fizinèse pratybose, gali atitolinti kognityvinių funkcijų blogèjimą.

Nors mokslininkai iki šiol diskutuoja dèl tikslaus fizinio aktyvumo poveikio mechanizmų smegenims, tačiau visi sutinka, kad aerobinis fizinis aktyvumas neabejotinai yra svarbūs sveikam smegenų senėjimui užtikrinti ir kogni- tyvinių funkcijų išsaugojimui vyresniame amžiuje.

Tyrimo tikslas - ịvertinti senyvo amžiaus asmenų griuvimams ịtakos turinčių fizinių, kognityvinių savybių raišką ir jų sąsajas.

\section{Tyrimo objektas ir metodai}

Tyrimo metodai: mokslinès literatūros analizė; testavimai, kūno apimčių ir kūno masès matavimai, apklausa žodžiu, statistinè duomenų analizè, naudojant SPSS 17 (aprašomoji statistika, vidurkių palyginimo $t$ testas, Anova testas, koreliacinè analizè). Tyrime taikyti testai aprašomi žemiau.

Plaštakos raumenų jẻgos matavimas. Tiriamųjų plaštakos raumenu jègai vertinti, buvo naudojamas plaštakos hidraulinis dinamometras. Raumenų jègos matavimo metu laikytasi standartinès procedūros:

1. Tiriamasis patogiai atsisèda ant kèdès.

2. Žastas pritrauktas ir nepasuktas ị išorę ar vidų.

3. Dilbis sulenktas $90^{\circ} \mathrm{kampu}$ ir neutralioje padetyje.

4. Plaštaka neutralioje padètyje arba tiesime (leidžiama amplitudè nuo $0^{\circ}$ iki $30^{\circ}$ ).

5. Plaštaka neutralioje padètyje arba pritraukime (leidžiama amplitude nuo $0^{\circ}$ iki $15^{\circ}$ ).

Prieš atliekant jègos matavimą, tiriamajam paaiškinama standartinè procedūra ir leidžiama išbandyti testą. Po penkių minučių testas kartojamas abiem rankomis, tris kartus maksimaliai suspaudžiant dinamometro hidraulinę rankeną. Fiksuojamas didžiausias pasiektas rezultatas. Vertinimas atliktas norint įvertinti sąsajas tarp valingos išvystomos raumenų jëgos ir kitų funkcinių rodiklių [3].

Dinaminès pusiausvyros vertinimas „Stotis ir eiti“ testu. „Stotis ir eiti“ testas atliktas tiriamujuc dinaminei pusiausvyrai įvertinti pagal standartizuotą protokolą. Dalyviai buvo paprašyti atsistoti nuo kẻdès ir nueiti 3 metrus iki linijos pabaigoje esančio kūgio, apsisukti $180^{\circ}$ ir grịžti atgal bei atsisèsti ant kèdès. Testo metu fiksuojamas laikas, per kurị tiriamasis atsistojo, nuejjo tris metrus, grịžo atgal ir atsisèdo [8].

Statinès pusiausvyros vertinimas modifikuotu „Rombergo“" testu. Statinè pusiausvyra vertinta modifikuotu Rombergo testu. Testas atliktas pagal standartizuotą protokolą (Rossiter et al.,1995). Testo metu tiriamasis buvo prašomas išstovèti dešimt sekundžių penkiose padètyse, rankas laikant pakeltas priešais save. Pusiausvyra vertinta tokiose padètys:

1. Pédos pečiu plotyje.

2. Pèdos suglaustos.

3. Viena pèda priekyje (tačiau ne vienoje linijoje).

4. Pèda prieš pėdą (vienos pèdos kulnas, kitos pėdos nykštys). 
Visi testai atlikti tiriamajam atsimerkus ir užsimerkus. Tiriamojo saugumo tikslais, paděčiu atlikimo metu, tiriamasis stovejo nugara ị sieną, o iš abiejų pusių vertinamaji saugojo tyrime dalyvavę tyrejjai [18].

Statinès pusiausvyros vertinimas naudojant, ,Sigma Balance PAD“. Tyrimas buvo atliekamas naudojant objektyvią pusiausvyros vertinimo platformą „Sigma Balance Pad“. Tyrimas buvo atliekamas pagal griežtus tyrimo atlikimo etapus, tokius kaip: a) platformos sukalibravimas; b) tiriamojo informavimas apie procedūrą bei perspejjimas, kaip elgtis, jei staiga prarastų pusiausvyrą; c) bandomasis pusiausvyros testavimas neregistruojant duomenų (buvo leidžiama 1-2 minutes pastovèti ant platformos); c) sociodemografinių duomenų surinkimas; d) pakartotinis platformos sukalibravimas; e) pusiausvyros testavimas kompiuterio pagalba registruojant duomenis (60 sekundžių). Tyrimo metu didelis dèmesys buvo skiriamas paciento būsenos sekimui ir saugumo užtikrinimui (saugiam užlipimui ir nulipimui nuo platformos).

Blauzdos ir žasto raumenų apimties matavimas. Tikslu ịvertinti tiriamujų raumenų apimties ir kitų funkcijų galimas sąsajas, buvo matuojamos abiejų blauzdų ir žastų apimtys centimetrine juostele. Blauzdų apimtis matuota storiausioje dvilypio blauzdos raumens vietoje, o žasto apimtis storiausioje dvigalvio žasto raumens vietoje. Matuojant blauzdų apimtis tiriamasis stovejo pečiu plotyje, vienodai paskirstęs svorį ant abiejų pedų, o matuojant žastų apimtis, vertinamasis stovejjo nuleidęs rankas išilgai kūno. Taip pat buvo vertinamas tiriamujų svoris ir ūgis, skaičiuojamas kūno masès indeksas (KMI).

Taip pat buvo naudojamas pusiau struktūruotas klausimynas (žodžiu). Šiuo klausimynu buvo siekiama išsiaiškinti sociodemografinius asmens duomenis, ịvertinti turimus susirgimus, fizinio aktyvumo raišką jaunysteje ir gyvenime bei šiuo metu taikomas fizinio aktyvumo formas.

Kadangi buvo naudojami keli tyrimo metodai, todèl vieno asmens ištyrimo laikas svyravo nuo 30 iki 45 minučių.

Protinès būklès vertinimas. Pacientu protinè būklè buvo vertinama naudojant Protinès būklès mini tyrimą. Protinès būklès mini tyrimas (angl. Mini-Mental State Examination MMSE) - tai plačiai klinikinejje praktikoje naudojamas struktūrizuotas pažintinių (kognityvinių) funkcijų tyrimo metodas. MMSE tiriamos tokios psichikos funkcijos kaip orientacija laiko ir vietos atžvilgiu, dèmesys, žodžių registracija ir atsiminimas, kalba, sugebejimas vykdyti žodines ir raštu pateiktas užduotis bei kopijuoti. MMSE vertinamas sudedant balus už kiekvieną teisingai atliktą užduotị. Minimalus testo rezultatas yra 0 , maksimalus - 30 balų. Kognityvinių funkcijų pažeidimo klasifikacija: 0-10 balų - sunkus kognityvinis sutrikimas, 11-20 balų - vidutinio sunkumo sutrikimas, 21-24 lengvas kognityvinis sutrikimas, 25 ir daugiau - kognityvinio pažeidimo nèra [10].

Tiriamieji. Tyrime dalyvavo 65 asmenys, kurių amžiaus vidurkis siekè 74,3 metų (standartinis nuokrypis 7,6 metai). Minimalus amžius - 60 metų, maksimalus -86 metai. Tiriamieji pagal amžiaus grupes pasiskirstè: $60-74 \mathrm{~m}$. $-41,3 \%, 75$ ir daugiau m. $-58,7 \%$.

Tiriamujuc atranka - netikimybinè tikslinè. Tyrime dalyvavo tikslinè pagyvenusių ir senų asmenų „mišri“ grupè, kuri pasižymėjo ịvairiomis sveikatos problemomis, susijusiomis su senatviniais pokyčiais. Asmenų, turinčių neurodegeneracines ligas, tokias kaip išsètinè sklerozè, Parkinso liga ir kt. tyrimo duomenys nèra ịtraukti ir nèra pristatomi šiame straipsnyje.

Didžioji dalis tiriamujų gyvena Kauno mieste ir Kauno rajone. Tyrimas buvo vykdomas Kauno miesto Y pirminès asmens sveikatos priežiūros centre ir tiriamujų namuose, kurie dèl apriboto judejjimo negalèjo patys atvykti ar būti atvežami ị tyrimą.

\section{Rezultatai}

Senyvo amžiaus asmenų statinè pusiausvyra buvo vertinama modifikuotu „Rombergo“ testu. Pusiausvyra buvo vertinama atsimerkus ir užsimerkus ir keliose padettyse (1 pav.).

Rombergo testo rezultatai tendencingai prastejja sudètingejjant šios užduoties reikalavimams (1 pav.). Tiriamiesiems geriau sekèsi atlikti Rombergo testą atsimerkus nei užsimerkus. Statinès pusiausvyros testą, kuomet pédos yra pečių plotyje, atliko 93,8 \% (atsimerkus) ir 82,8 \% (užsimerkus). Esant pédoms suglaustoms - 82,8 \% (atsimerkus) ir $60,9 \%$ (užsimerkus). Pastačius vieną pėdą priekyje užduoti atliko 65,6 \% (atsimerkus) ir 39,1 \% (užsimerkus). Ganètinai sunkiai sekèsi atlikti Rombergo testą, kuomet reikejjo išlaikyti pusiausvyrą pastačius pedą prieš pèdą. Šią užduoti atsimerkus atliko 34,4 \% ir tik 4,7 \% užsimerkus.

Užduoties „Atsistoti ir eiti“ atlikimo laiko vidurkis 15,9 sek. (st. nuokrypis 10,1 sek.). Trumpiausias atlikimo laikas $-6,4$ sekendès, ilgiausias -50 sek. $38,1 \%$ tiriamujų užduoties atlikimo laikas svyravo nuo 6,40 iki 10,59 sek. Panaši dalis šią užduotị atliko šiek tiek ilgiau, kuomet užfiksuotas laikas siekè nuo 11 iki 15,59 sek. 22,2 \% tiriamųjų užduoti atliko per 16 - 30,59 sek. Tačiau $9,5 \%$ užduoties atlikimo laikas siekè 31 sek. ir daugiau (2 pav.).

Minimalios protinès veiklos testas (MMSE) parodè, kad 68,8 \% senyvo amžiaus asmenų pasižymi normaliomis kognityvinemis funkcijomis, $17,2 \%$ nustatytas lengvas ir $14,1 \%$ vidutinis kognityvinių funkcijų sutrikimas. Minimalios protinès veiklos testo vidurkis siekè 25,1 (standartinis 
nuokrypis - 4,58, minimali reikšmè - 12 , maksimali -30). Taigi aiškiai matyti skirtumai tarp MMSE rezultatų tirtoje grupeje (3 pav.).

Vertinant rankų jègą standartiniu dinamometru nustatyta, kad dešinèje rankoje ji siekè $24,8 \mathrm{~kg}$ (standartinis nuokrypis $11,3 \mathrm{~kg}$, minimali reikšmè 0 , maksimali 48). Kairès rankos suspaudimo jèga siekè $24,1 \mathrm{~kg}$ (standartinis nuokrypis $11,1 \mathrm{~kg}$, minimali reikšmè 0 , maksimali 49) (4 pav.).

Tikslu įvertinti tiriamujų raumenų apimties ir kitų funkcijų galimas sąsajas, buvo matuojamos abiejų blauzdų ir žastų apimtys centimetrine juostele.

1 lentelëje matyti, kad tirtoje asmenų grupejje raumenų apimtis mažai skiriasi kairiojo ir dešiniojo žasto bei dešiniosios, ir kairiosios blauzdos srityse $(\mathrm{p} \geq 0,05)$. Kairès rankos žasto apimtis $-31,9 \mathrm{~cm}$, dešinès $-32,5 \mathrm{~cm}$, kairès blauzdos apimtis $-38,3 \mathrm{~cm}$, dešinès $-38,2 \mathrm{~cm}$.

Statine pusiausvyra buvo vertinama naudojant programini pusiausvyros aparatą "Sigma Balance PAD". Tačiau šiuo aparatu pusiausvyra buvo vertinama ne visiems, o tik tiems, kurie savarankiškai sugebejo išstovèti ant nestabilios platformos (tyrèjams šalia stovint ir prižiūrint). Aparatu "Sigma Balance Pad" pusiausvyra buvo vertinta $71,9 \%$.

Tyrime dalyvavusių asmenų grupeje vaizdinio ilgis siekè 12,6 cm, (standartinis nuokrypis 8,6, minimali reikšmé $3,57 \mathrm{~cm}$, maksimali $-42,47 \mathrm{~cm}$ ). Vaizdinio plotas $0,46 \mathrm{~cm}^{2}$ (standartinis nuokrypis 0,587 , minimali reikšmé 0,02, maksimali - 42,47).

Šiuo tyrimu taip pat buvo siekiama ịvertinti dažniausiai taikomas fizinio aktyvumo formas. Dažniausiai šios amžiaus grupès asmenys praktikuoja pasivaiščiojimą lauke $(54,7 \%)$, sodininkystę-daržininkystę $(26,6 \%)$, važinèjimą dviračiu $(6,3 \%)$ ir baseino lankymą $(6,3 \%)$. Fizinio aktyvumo indeksas buvo išvestas susumavus ir išvedus vidurkị iš šių fizinio aktyvumo formų, kurios yra aktyviai taikomos pagyvenusių ir senų asmenų grupeje: pasivaikščiojimas, bėgiojimas, važinejjimas dviračiu, plaukimas baseine, ejjimas su šiaurietiškomis lazdomis, darbas sode-darže, dalyvavimas šokių užsièmimuose.

Taikyta koreliacinè analizè (Spearmen'o koreliacijos koeficientas) leido nustatyti statistinius sąryšius tarp tyrime dalyvavusių senyvo amžiaus asmenų fizinių ir kognityvinių savybių (2 lentelè). Nustatytas vidutinis, o kai kuriais atvejais ir stiprus statistinis ryšys tarp dešinès ir kairès rankos jègos, kuri buvo matuojama dinamometru, ir statinès bei dinaminès pusiausvyros, blauzdų apimties ir net protinių funkcijų, tirtų MMSE. Vertinant statinę pusiausvyrą gauti statistiškai reikšmingi skirtumai, rodantys, kad pusiausvyos vertinimo metu pieštas vaizdnio ilgis yra susijęs su vaizdinio plotu (stiprus koreliacinis ryšys). Taip pat vaizdinio ilgis statistiškai reikšmingai susijęs su tiriamujų blauzdų apimtimi (silpnas statistinis ryšys). O tai reiškia, kad asmenys, kurių blauzdos yra stambesnès, geriau atliko statinès pusiausvyros užduotị naudojant aparatą

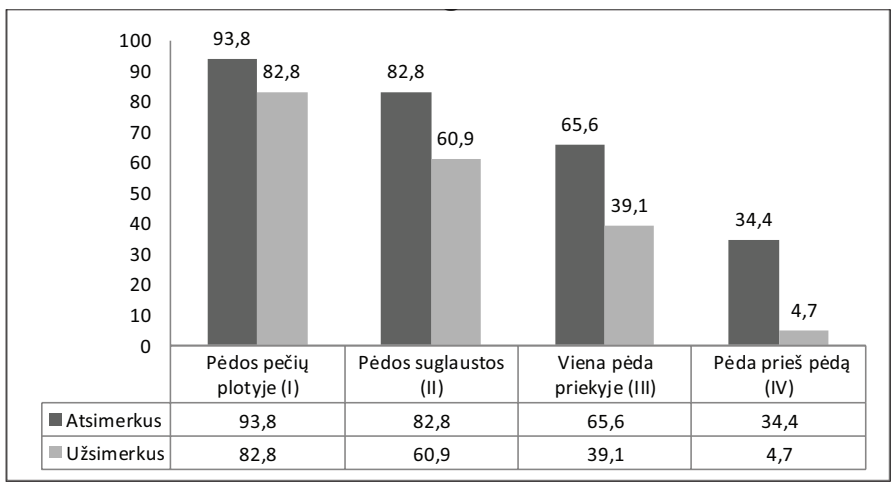

1 pav. Statinès pusiausvyros vertinimas naudojant Rombergo testą (procentai)

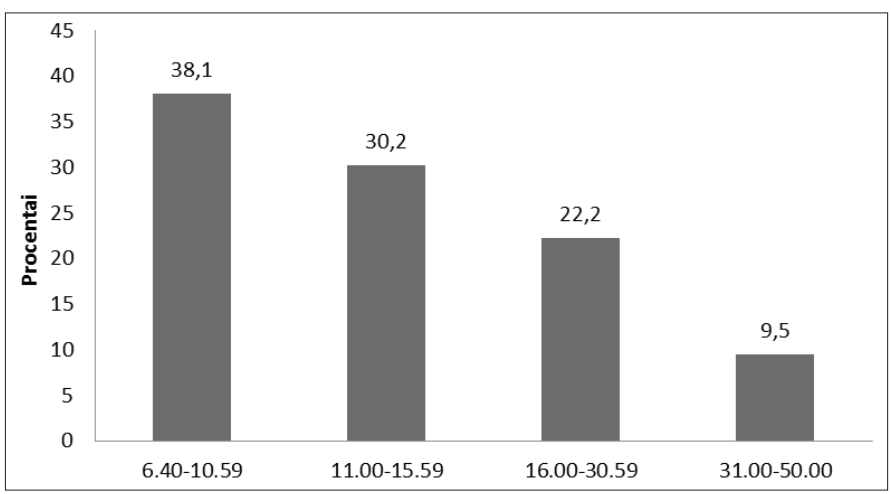

2 pav. Užduoties „Atsistoti ir eiti““ atlikimo laikas

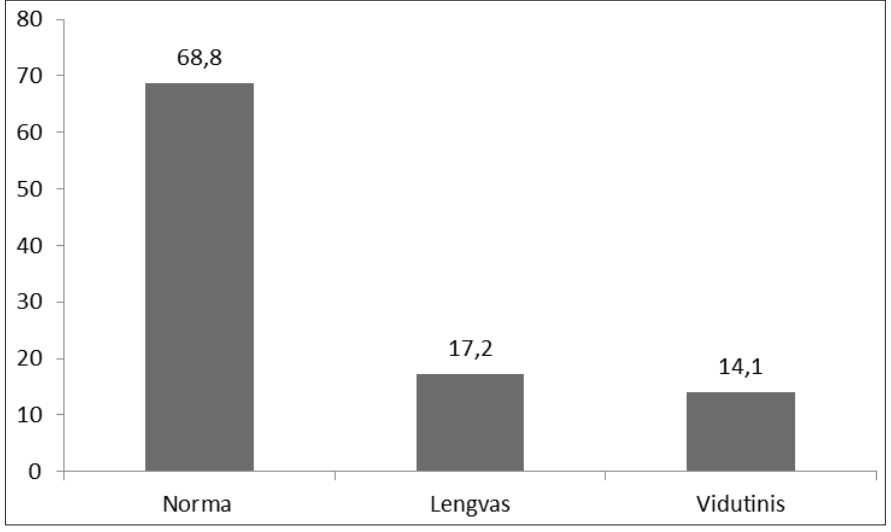

3 pav. Minimalios protinès veiklos testo atlikimo rezultatai (MMSE) 


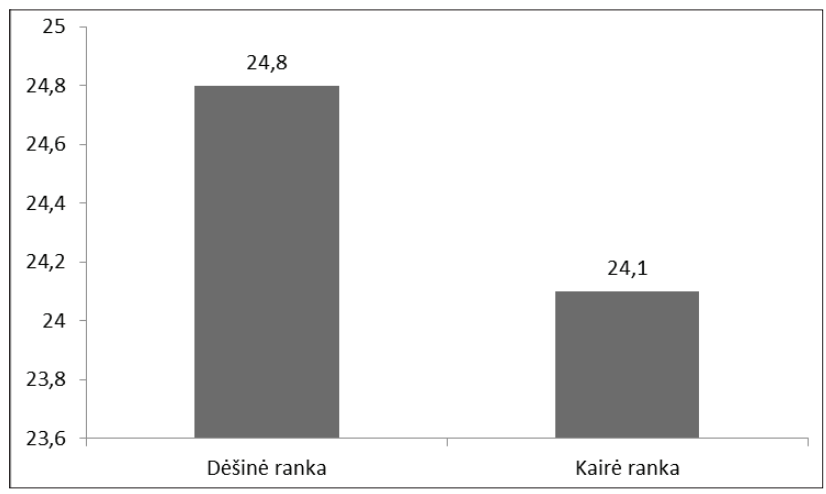

4 pav. Rankų jègos matavimas naudojant plaštakos hidraulinį dinamometrą $(\mathrm{kg})$

1 lentelè. Žąstų ir blauzdų apimties matavimas $(\mathrm{cm})$

\begin{tabular}{|l|c|c|c|c|}
\hline Statistiniai rodikliai & $\begin{array}{c}\text { Žasto } \\
\text { apimtis } \\
\text { kaire் }\end{array}$ & $\begin{array}{c}\text { Žasto } \\
\text { apimtis } \\
\text { dešine் }\end{array}$ & $\begin{array}{c}\text { Blauzdos } \\
\text { apimtis } \\
\text { kaire் }\end{array}$ & $\begin{array}{c}\text { Blauzdos } \\
\text { apimtis } \\
\text { dešine் }\end{array}$ \\
\hline Vidurkis & 31,9 & 32,5 & 38,3 & 38,2 \\
\hline Standartinis nuokrypis & 5,03 & 5,46 & 4,76 & 4,65 \\
\hline Minimali reikšmė & 22,00 & 23,00 & 29,50 & 30,00 \\
\hline Maksimali reikšmé & 50,00 & 50,00 & 60,00 & 61,00 \\
\hline
\end{tabular}

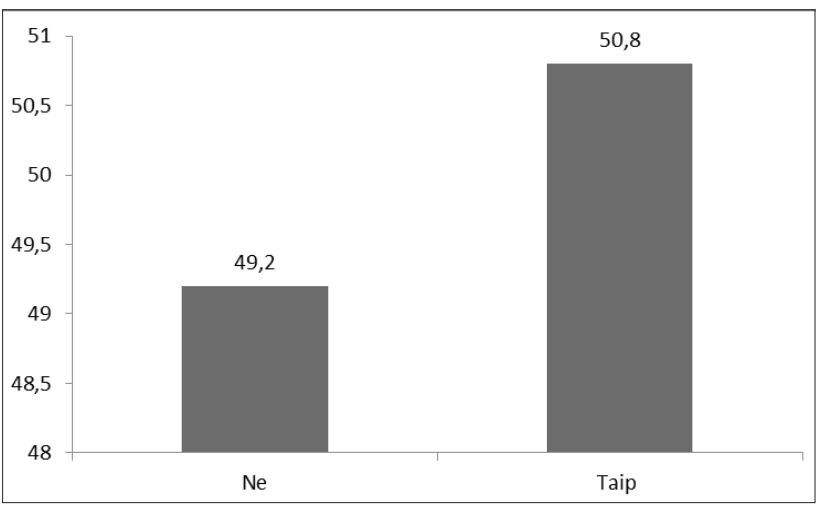

5 pav. Patirti griuvimai per paskutinius šešis mènesius

„Sigma Balance Pad“. Nustatyta, kad asmenys, kurie šiuo metu fiziškai aktyviai gyvena (praktikuoja pasivaikščiojimą, darbą sode ar pan.), pasižymi geresniais dinaminès pusiausvyros rodikliais ir geresnèmis protinėmis savybėmis $(\mathrm{p} \leq 0,05)$. Išryškejjo įdomus faktas $(\mathrm{p} \leq 0,05)$, rodantis jog nepakankamos mitybos asmenys, kurių kūno masės indeksas (KMI) yra žemesnis nei norma, praščiau atliko protines veiklas vertinantį testą (MMSE).

Tyrimas padejo atskleisti griuvimų raišką tirtoje seny-

2 lentelè. Fizinių ir kognityvinių savybių sąsajos (Spearman'o koreliacijos koeficietas)

P.s. Koreliacijos koeficiento $(R)$ reikšmess: * - 0 - 0.3 silpnas ryšys; ** - 0,3 - 0.7 vidutinis ryšys; ** - 0,7 - 1 stiprus ryšys

\begin{tabular}{|c|c|c|c|c|c|c|c|c|c|c|c|c|}
\hline $\begin{array}{l}\text { Matavimai } \\
\text { ir testai }\end{array}$ & $\begin{array}{c}\text { Kairès } \\
\text { rankos } \\
\text { jèga }\end{array}$ & $\begin{array}{c}\text { Dešinės } \\
\text { rankos } \\
\text { jẻga }\end{array}$ & $\begin{array}{l}\text { Atsisto- } \\
\text { ti ir eiti } \\
\text { užduo- } \\
\text { tis }\end{array}$ & $\begin{array}{l}\text { Vaizdi- } \\
\text { nio ilgis } \\
\text { - Sigma }\end{array}$ & $\begin{array}{c}\text { Vaiz- } \\
\text { dinio } \\
\text { plotas - } \\
\text { Sigma }\end{array}$ & MMSE & KMI & $\begin{array}{c}\text { Rom- } \\
\text { bergo } \\
\text { testai } \\
\text { atsi- } \\
\text { merkus }\end{array}$ & $\begin{array}{c}\text { Rom- } \\
\text { bergo } \\
\text { testai } \\
\text { užsi- } \\
\text { merkus }\end{array}$ & $\begin{array}{c}\text { Fizinio } \\
\text { akty- } \\
\text { vumo } \\
\text { indek- } \\
\text { sas }\end{array}$ & $\begin{array}{c}\text { Žastų } \\
\text { apimtis }\end{array}$ & $\begin{array}{c}\text { Blauz- } \\
\text { dų ap- } \\
\text { imtis }\end{array}$ \\
\hline $\begin{array}{l}\text { Kairès ran- } \\
\text { kos jèga }\end{array}$ & & $\mathbf{0 , 8 9 7 * *}$ & $0,651 * *$ & 0,22 & 0,159 & $0,391 * *$ & 0,22 & $0,421 * *$ & $0,372 * *$ & $0,271 *$ & 0,22 & $0,388 * *$ \\
\hline $\begin{array}{l}\text { Dešinès } \\
\text { rankos jėga }\end{array}$ & $\mathbf{0}, 897 * *$ & & $0,680 * *$ & 0,205 & 0,038 & $0,435 * *$ & 0,16 & $0,419 * *$ & $0,363 * *$ & $0,317^{*}$ & 0,19 & $0,339 * *$ \\
\hline $\begin{array}{l}\text { Atsistoti ir } \\
\text { eiti užduotis }\end{array}$ & $0,651 * *$ & $0,680 * *$ & & 0,036 & 0,001 & $0,558 * *$ & $-0,2$ & $0,601 * *$ & $0,538 * *$ & $0,478 * *$ & $0,283^{*}$ & $0,378 * *$ \\
\hline $\begin{array}{l}\text { Vaizdinio } \\
\text { ilgis - Sigma }\end{array}$ & 0,22 & 0,205 & 0,036 & & $0,826 * *$ & 0,28 & 0,02 & 0,083 & 0,212 & $-0,1$ & 0,09 & $0,297 *$ \\
\hline $\begin{array}{l}\text { Vaizdinio } \\
\text { plotas - Si- } \\
\text { gma }\end{array}$ & 0,159 & 0,038 & 0,001 & $0,826 * *$ & & 0,28 & 0 & 0,008 & 0,244 & $-0,2$ & 0,08 & 0,21 \\
\hline MMSE & $0,391 * *$ & $0,435 * *$ & $0,558 * *$ & 0,279 & 0,276 & & $0,436^{* *}$ & $0,498 * *$ & $0,402 * *$ & $0,308^{*}$ & $0,288^{*}$ & $0,432 * *$ \\
\hline KMI & 0,218 & 0,163 & 0,243 & 0,021 & 0,004 & $0,436 * *$ & & 0,2 & 0,06 & 0,1 & $0,692 * *$ & $0,697 * *$ \\
\hline $\begin{array}{l}\text { Rombergo } \\
\text { testai atsi- } \\
\text { merkus }\end{array}$ & $0,421 * *$ & $0,419 * *$ & $0,601 * *$ & 0,083 & 0,008 & $0,498 * *$ & 0,2 & & $0,818 * *$ & $0,409 * *$ & $0,341 * *$ & $0,367 * *$ \\
\hline $\begin{array}{l}\text { Rombergo } \\
\text { testai užsi- } \\
\text { merkus }\end{array}$ & $0,372 * *$ & $0,363 * *$ & $\mathbf{0 , 5 3 8 * *}$ & 0,212 & 0,244 & $0,402 * *$ & 0,06 & $0,818 * *$ & & $0,323 * *$ & 0,22 & $0,325 * *$ \\
\hline $\begin{array}{l}\text { Fizinio } \\
\text { aktyvumo } \\
\text { indeksas } \\
\end{array}$ & $0,271 *$ & $0,317 *$ & $0,478 * *$ & 0,141 & $-0,203$ & $0,308 *$ & $-0,1$ & $0,409 * *$ & $0,323 * *$ & & 0,03 & 0,03 \\
\hline
\end{tabular}


vo amžiaus asmenų populiacijoje (5 pav.). Net kas antras tyrime dalyvavęs asmuo patyre griuvimus per pastaruosius šešis mėnesius $(50,8$ \%). Tokia didelè griuvimų raiška verčia giliau ieškoti griuvimų sąsajų su fizinèmis ir kognityvinėmis tiriamujų savybėmis.

Taikant dviejų grupių palyginimo testą (T testą) nustatyta, kad tyrime dalyvavę asmenys, kurie per pastaraji pusmeti nepatyrè griuvimų, pasižymi stipresne kairès bei dešinès rankos jèga (3 lentelè). Pvz., per minètą laikotarpị nepatyrusių griuvimų dešinès rankos jëga siekẻ $30,6 \mathrm{~kg}$, patyrusių - 19,8 kg ( $\mathrm{p}=0,000)$, dešinès rankos $29 \mathrm{~kg}$, kairès $-20 \mathrm{~kg}(\mathrm{p}=0,010)$. Užduoti „Atsistoti ir eiti“" greičiau atliko (11,2 sek.) griuvimus nepatyrusių asmenų grupè nei griuvimus patyrusių grupe (20,6 sek.). Susumavus Rombergo testo rezultatus ir išvedus vidutinị ịvertị paaiškejjo, kad griuvimus nepatyrusių asmenų grupe pasižymi geresniais statinès pusiausvyros rodikliais $(\mathrm{p} \leq 0,05)$. Fizinio aktyvumo nauda nediskutuojama ir vyresniame amžiuje, nes tyrimas parodè, kad asmenys, kurie fiziškai yra aktyvesni (praktikuoja pasivaikščiojimą, darbą sode, darže ir pan.), rečiau patiria griuvimus $(\mathrm{p}=0,05)$.

Tyrimas parodè, kad fiziniai ir kognityvinių funkcijų

3 lentelè. Per pastaraji pusmetị patyrusių ir nepatyrusių griuvimus fizinių ir kognityvinių savybių skirtumai

\begin{tabular}{|c|c|c|c|}
\hline Matavimai ir testai & $\begin{array}{c}\mathbf{P} \\
\text { reikš- } \\
\text { mé }\end{array}$ & $\begin{array}{c}\text { Patyrusių } \\
\text { griuvimus } \\
\text { asmenų } \\
\text { grupė (Vi- } \\
\text { durkiai) }\end{array}$ & $\begin{array}{c}\begin{array}{c}\text { Nepa- } \\
\text { tyrusių }\end{array} \\
\text { griuvimus } \\
\text { asmenų } \\
\text { grupè (Vi- } \\
\text { durkiai) }\end{array}$ \\
\hline Kairès rankos jèga & 0,010 & 20,0 & 29,0 \\
\hline Dešinès rankos jèga & 0,000 & 19,8 & 30,6 \\
\hline $\begin{array}{l}\text { Užduotis „Atsistoti } \\
\text { ir eiti“ }\end{array}$ & 0,000 & 20,6 & 11,2 \\
\hline $\begin{array}{l}\text { Vaizdinio ilgis (Si- } \\
\text { gma) }\end{array}$ & 0,350 & 14,2 & 11,7 \\
\hline $\begin{array}{l}\text { Vaizdinio plotas } \\
\text { (Sigma) }\end{array}$ & 0,283 & 0,60 & 0,38 \\
\hline $\begin{array}{l}\text { Rombergo „Atsi- } \\
\text { merkus“ (IV) testų } \\
\text { vidurkiai }\end{array}$ & 0,010 & 0,56 & 0,81 \\
\hline $\begin{array}{l}\text { Rombergo „Užsi- } \\
\text { merkus“ (IV) testų } \\
\text { vidurkiai }\end{array}$ & 0,000 & 0,33 & 0,60 \\
\hline $\begin{array}{l}\text { Minimalios protinès } \\
\text { veiklos vertinimas } \\
\text { (MMSE) }\end{array}$ & 0,000 & 24 & 26,3 \\
\hline Kūno masės indeksas & 0,78 & 28,4 & 28,9 \\
\hline $\begin{array}{l}\text { Fizinio aktyvumo } \\
\text { indeksas }\end{array}$ & 0,05 & 0,1 & 0,15 \\
\hline Žastų apimtis & 0,340 & 31,6 & 32,9 \\
\hline Blauzdų apimtis & 0,397 & 37,8 & 38,7 \\
\hline
\end{tabular}

rodikliai statistiškai reikšmingai skiriasi pagal amžių (4 lentelè). Sugrupavus tiriamujų amžių ị dvi grupes (pirma grupe 60-74 metai, antra grupe 75 ir daugiau metų) nustatyta, kad visi rodikliai yra prastesni 75 ir daugiau metų turinčių asmenų grupejje. Šios amžiaus grupès asmenys prasčiau atliko pusiausvyrą ir kognityvines funkcijas vertinančius testus ( $T$ testas, $p \leq 0,05$ ). Tyrime dalyvavusių vyresnių asmenų grupèje nustatyta silpnesnè ranku jèga, mažesnè žasto bei blauzdu apimtis, jie praščiau atliko dinaminę ir statinę pusiausvyrą vertinančius testus ( $T$ testas, $p \leq 0,05$ ). Tarp

4 lentelė. Fizinių ir kognityvinių savybių skirtumai pagal amžiaus grupes

\begin{tabular}{|c|c|c|c|}
\hline Matavimai ir testai & $\begin{array}{l}\text { P reikš- } \\
\text { mé }\end{array}$ & $\begin{array}{c}\text { Amžiaus } \\
\text { grupès }\end{array}$ & Vidurkiai \\
\hline \multirow[b]{2}{*}{ Kairès ranka jèga } & \multirow[b]{2}{*}{0,003} & $65-74$ & 29,16 \\
\hline & & $\begin{array}{c}75 \text { ir dau- } \\
\text { giau }\end{array}$ & 21,19 \\
\hline \multirow[b]{2}{*}{ Dešinès rankos jèga } & \multirow[b]{2}{*}{0,001} & $65-74$ & 30,44 \\
\hline & & $\begin{array}{c}75 \text { ir dau- } \\
\text { giau }\end{array}$ & 21,38 \\
\hline \multirow{2}{*}{$\begin{array}{l}\text { Užduotis ,Atsistoti } \\
\text { ir eiti“ }\end{array}$} & \multirow[b]{2}{*}{0,010} & $65-74$ & 10,62 \\
\hline & & $\begin{array}{l}75 \text { ir dau- } \\
\text { giau }\end{array}$ & 19,81 \\
\hline \multirow{2}{*}{$\begin{array}{l}\text { Vaizdinio ilgis (,Si- } \\
\text { gma“) }\end{array}$} & \multirow[b]{2}{*}{0,029} & $65-74$ & 9,98 \\
\hline & & $\begin{array}{c}75 \text { ir dau- } \\
\text { giau }\end{array}$ & 15,75 \\
\hline \multirow{2}{*}{$\begin{array}{l}\text { Vaizdinio plotis („Si- } \\
\text { gma“) }\end{array}$} & \multirow[b]{2}{*}{0,023} & $65-74$ & 0,27 \\
\hline & & $\begin{array}{c}75 \text { ir dau- } \\
\text { giau }\end{array}$ & 0,68 \\
\hline \multirow{2}{*}{$\begin{array}{l}\text { Rombergo „Atsi- } \\
\text { merkus“(IV) testų } \\
\text { vidurkiai }\end{array}$} & \multirow[b]{2}{*}{0,000} & $65-74$ & $\mathbf{0 , 8 5}$ \\
\hline & & $\begin{array}{c}75 \text { ir dau- } \\
\text { giau }\end{array}$ & $\mathbf{0 , 5 7}$ \\
\hline \multirow{2}{*}{$\begin{array}{l}\text { Rombergo „Už- } \\
\text { merkus“ (IV) testų } \\
\text { vidurkiai }\end{array}$} & \multirow{2}{*}{0,001} & $65-74$ & 0,61 \\
\hline & & $\begin{array}{l}75 \text { ir dau- } \\
\text { giau }\end{array}$ & 0,36 \\
\hline \multirow{2}{*}{$\begin{array}{l}\text { Minimalios protinès } \\
\text { veiklos vertinimas } \\
\text { (MMSE) }\end{array}$} & \multirow[b]{2}{*}{0,000} & $65-74$ & 28,12 \\
\hline & & $\begin{array}{c}75 \text { ir dau- } \\
\text { giau }\end{array}$ & 22,95 \\
\hline \multirow[b]{2}{*}{ Kūno masės indeksas } & \multirow[b]{2}{*}{0,012} & $65-74$ & 31,26 \\
\hline & & $\begin{array}{l}75 \text { ir dau- } \\
\text { giau }\end{array}$ & 26,95 \\
\hline \multirow{2}{*}{$\begin{array}{l}\text { Fizinio aktyvumo } \\
\text { indeksas }\end{array}$} & \multirow[b]{2}{*}{0,023} & $65-74$ & 0,17 \\
\hline & & $\begin{array}{c}75 \text { ir dau- } \\
\text { giau }\end{array}$ & 0,09 \\
\hline \multirow[b]{2}{*}{ Žastų apimtis } & \multirow[b]{2}{*}{0,001} & $65-74$ & 34,88 \\
\hline & & $\begin{array}{l}75 \text { ir dau- } \\
\text { giau }\end{array}$ & 30,47 \\
\hline \multirow[b]{2}{*}{ Blauzdų apimtis } & \multirow[b]{2}{*}{$\mathbf{0 , 0 0 0}$} & $65-74$ & 40,76 \\
\hline & & $\begin{array}{l}75 \text { ir dau- } \\
\text { giau }\end{array}$ & 36,60 \\
\hline
\end{tabular}


5 lentelè. Fizinių ir kognityvinių savybių skirtumai pagal gyvenime praktikavusių fizinį aktyvumą (FA) grupes

\begin{tabular}{|l|c|c|c|}
\hline Matavimai ir testai & $\begin{array}{c}\text { P } \\
\text { reikš- } \\
\text { mé }\end{array}$ & $\begin{array}{c}\text { Gyvenime } \\
\text { prakti- } \\
\text { kavusių } \\
\text { sFA grupé } \\
\text { (Vidur- } \\
\text { kiai) }\end{array}$ & $\begin{array}{c}\text { Gyvenime } \\
\text { neprakti- } \\
\text { kavusių FA } \\
\text { grupė (Vi- } \\
\text { durkiai) }\end{array}$ \\
\hline Kairès rankos jèga & 0,001 & 28,5 & 21,9 \\
\hline Dešinės rankos jèga & 0,001 & 29,4 & 22,4 \\
\hline Užduotis „Atsistoti ir eiti“ & 0,001 & 11,3 & 18,5 \\
\hline Vaizdinio ilgis (Sigma) & 0,167 & 10,6 & 14,0 \\
\hline Vaizdinio plotas (Sigma) & 0,367 & 0,38 & 0,53 \\
\hline $\begin{array}{l}\text { Rombergo „Atsimerkus“ } \\
\text { (IV) testų vidurkiai }\end{array}$ & 0,119 & 0,76 & 0,64 \\
\hline $\begin{array}{l}\text { Rombergo „Užsimerkus“ } \\
\text { (IV) testų vidurkiai }\end{array}$ & 0,010 & 0,58 & 0,39 \\
\hline $\begin{array}{l}\text { Minimalios protinės vei- } \\
\text { klos vertinimas (MMSE) }\end{array}$ & 0,05 & 26,4 & 24,3 \\
\hline Kūno masės indeksas & 0,748 & 28,1 & 28,9 \\
\hline Fizinio aktyvumo indeksas & 0,05 & 0,16 & 0,10 \\
\hline Žastų apimtis & 0,953 & 32,3 & 32,2 \\
\hline Blauzdų apimtis & 0,083 & 38,5 & 38,2 \\
\hline
\end{tabular}

šių asmenų nustatytas mažesnis fizinio aktyvumo lygmuo, taip jie pasižymėjo prastesnèmis protinèmis savybėmis, vertintomis taikant MMSE ( $\mathrm{T}$ testas, $\mathrm{p} \leq 0,05$ ).

5 lentelëje aiškiai matyti, kad fizinis aktyvumas jaunystejje - pamatas geriems fiziniams ir kognityviniams rodikliams vyresniame amžiuje. Taikant dviejų grupių vidurkių palyginimo $\mathrm{T}$ testą paaiškejjo, kad asmenys, kurie jaunystèje ir gyvenime buvo fiziškai aktyvūs, pasižymi didesne dešinès ir kairés rankos jèga $(p=0,01)$. Fiziškai aktyvesni asmenys geriau atliko dinaminę pusiausvyrą vertinančią užduoti „Atsistoti ir eiti“ $(\mathrm{p}=0,01)$ bei geresni buvo Rombergo testo užsimerkus, kuris yra skirtas vertinti statinę pusiausvyrą, rezultatai $(\mathrm{p}=0,01)$. Asmenys, kurie jaunysteje ir gyvenime buvo fiziškai aktyvesni - šią praktiką dažniau diegia vyresniame amžiuje $(\mathrm{p}=0,05)$.

Vertinant fizinių ir kognityvinių savybių skirtumus pagal profesijos pobūdi nustatyta, kad asmenys, gyvenime dirbę protinị darbą, pasižymi geresniais kai kuriais fiziniais duomenimis ir kognityvinèmis savybėmis. Šių asmenų grupèje, skirtingai nei fizinị darbą dirbusių asmenų grupeje, nustatyta didesnè dešinès ir kairiosios rankos jèga, geriau atliko testą „Atsistoti ir eiti“ bei geriau atliko kognityvines funkcijas vertinantị testą. Protinị darbą dirbusių asmenų grupejje kairès rankos jèga siekia 26,8 kg, dešiniosios 28,6 $\mathrm{kg}$, kai tuo tarpu fizini darbą dirbusių asmenų grupejje šie rodmenys yra keliais kilogramais mažesni $(\mathrm{p} \leq 0,05)$. Nustatyta $(\mathrm{p} \leq 0,05), \mathrm{kad}$ asmenų, gyvenime dirbusių protini darbą trumpesnis užduoties "Atsistoti ir eiti" atlikimo laikas. Asmenys, kurių profesinè veikla pasižymėjo daugiau protinèmis, nei fizinèmis funkcijomis, geriau atliko protinę veiklą vertinanti testą - MMSE $(\mathrm{p} \leq 0,05)$.

\section{Išvados}

1. Rombergo testo rezultatai tendencingai prastejja sudètingèjant šios užduoties reikalavimams. Tiriamiesiems geriau sekèsi atlikti Rombergo testą atsimerkus nei užsimerkus. Užduoties „Atsistoti ir eiti“ atlikimo laiko vidurkis - 15,9 sek. Minimalios protinès veiklos testas (MMSE) parodè, kad daugiau nei 2/3 pagyvenusių ir senų asmenų pasižymi normaliomis kognityvinemis funkcijomis, likusieji turi šių funkcijų mažesnių ar didesnių sutrikimų.

2. Vertinant ranku jègą standartiniu dinamometru nustatyta, kad dešinejje ir kairèje rankoje ji vidutiniškai sieké $24 \mathrm{~kg}$. Kairès rankos žasto apimtis $-31,9 \mathrm{~cm}$, dešinès $32,5 \mathrm{~cm}$, kairès blauzdos apimtis $-38,3 \mathrm{~cm}$, dešinès $-38,2$ $\mathrm{cm}$. Statinè pusiausvyra buvo vertinama naudojant programini pusiausvyros aparatą "Sigma Balance PAD". Tačiau šiuo aparatu pusiausvyra buvo vertinama ne visiems, o tik tiems, kurie savarankiškai sugebejjo išstovèti ant nestabilios platformos. Šiuo aparatu pusiausvyra buvo vertinta $71,9 \%$. Vaizdinio ilgis siekė $12,6 \mathrm{~cm}$, o vaizdinio plotas $0,46 \mathrm{~cm} 2$.

3. Nustatytas statistinis tyšys tarp dešinès ir kairès rankos jègos, kuri buvo matuojama dinamometru ir statinés bei dinaminès pusiausvyros, blauzdų apimties ir net protinių funkcijų. Vertinant statinę pusiausvyrą gauti statistiškai reikšmingi skirtumai rodo, kad pusiausvyros vertinimo metu pieštas vaizdnio ilgis yra susijęs su vaizdinio plotu (stiprus koreliacinis ryšys). Taip pat vaizdinio ilgis statistiškai reikšmingai susijęs su tiriamujų blauzdu apimtimi. Nustatyta, kad asmenys, kurie šiuo metu fiziškai aktyviai gyvena, pasižymi geresniais dinaminès pusiausvyros rodikliais ir gerenemis protinèmis savybėmis. Nepakankamos mitybos asmenys, kurių kūno masès indeksas (KMI) yra žemesnis nei norma, praščiau atliko MMSE. Šios išvados statistiškai reikšmingos $(\mathrm{p} \leq 0,05)$.

4. Tyrime dalyvavę asmenys, kurie per pastaraji pusmetị nepatyre griuvimų, pasižymi stipresne kairès bei dešinès rankos jèga $(p \leq 0,05)$. Užduoti „Atsistoti ir eiti“ greičiau atliko griuvimus nepatyrusių asmenų grupe $(p \leq 0,05)$. Griuvimus nepatyrusių asmenų grupė pasižymi geresniais statinès pusiausvyros rodikliais $(\mathrm{p} \leq 0,05)$. Asmenys, kurie fiziškai yra aktyvesni (praktikuoja pasivaikščiojimą, darbą sode, darže ir pan.), rečiau patiria griuvimus $(\mathrm{p} \leq 0,05)$. 
5. Fiziniai ir kognityviniai rodikliai statistiškai reikšmingai skiriasi pagal amžių. Visi rodikliai yra prastesni 75 ir daugiau metų turinčių asmenų grupejje. Šios amžiaus grupès asmenys prasčiau atliko pusiausvyrą ir kognityvines funkcijas vertinančius testus. Tarp šių asmenų nustatytas mažesnis fizinio aktyvumo lygmuo, jie pasižymėjo prastesnèmis protinėmis savybėmis, vertintomis taikant MMSE $(p \leq 0,05)$. Asmenys, kurie jaunysteje ir gyvenime buvo fiziškai aktyvūs, pasižymi geresniais fiziniais ir kognityviniais rodikliais $(\mathrm{p} \leq 0,05)$.

\section{Literatūra}

1. Anderson RN, Smith BL. Deaths: leading causes for. National Vital Statistics reports. 2002; 53. Hyattsville, MD: National Center for Health Statistics, 2005; 17.

2. Bams JL, Miranda DR. Outcome and costs of intensive care. Int Care Med 1985;11:234-41.

3. Beseler MR, Rubio C, Duarte E, Hervás D, Guevara MC, GinerPascual M, Vioscal E. Clinical effectiveness of grip strength in predicting ambulation of elderly inpatients. Clin Interv Ageing 2014; 9: 1873-1877.

https://doi.org/10.2147/CIA.S62002

4. Brooke-Wavell K, Athersmith LE, Jones PR, Masud T. Brisk walking and postural stability: cross-sectional study in postmenopausal women. Gerontol 1998; 44 (5): 288-92.

https://doi.org/10.1159/000022028

5. Busse AL, Gil G, Santarem JM, Filho WJ. Physical Activity and cognition in the elderly. Dementia\&Neuropsychologia, 2009; September 3(3): 204-208.

https://doi.org/10.1590/S1980-57642009DN30300005

6. Cooper C. The crippling consequences of fractures and their impact on quality of life. Am J Med 1997; 103:125-75. https://doi.org/10.1016/S0002-9343(97)90022-X

7. Ducher G, Jaffre C, Arlettaz A, Benhamou CL, Courteix D. Effects of long-term tennis playing on the muscle-bone relationship in the dominant and nondominant forearms. Can J Appl Physiol 2005; 30:3-17.

https://doi.org/10.1139/h05-101

8. Duncan PW, Weiner DK, Chandler J, Studenski S. Functional reach: a new clinical measure of balance. J Gerontol 1990; 45: M192-M197. https://doi.org/10.1093/geronj/45.6.M192 https://doi.org/10.1093/geronj/45.6.M192

9. Evans WJ. What is sarcopenia? J Gerontol A Biol Sci Med Sci 1995; 50:5-8. https://doi.org/10.1093/gerona/50A.Special_Issue.5

10. Folstein MP, Folstein SE, McHugh Pro. Mini-Mental State": a practical method of grading the cognitive state of patients for the clinician. J Psychiatr Res 1975; 12: 189-198. https://doi.org/10.1016/0022-3956(75)90026-6

11. Frost HM. Onourage-related boneloss: insights from a new paradigm. J Bone Miner Res 1997; 12:1-9. 48.
12.Gelder BM, MSc, Tijhuis MSR, PhD, Kalmijn S, MD, PhD, Giampaoli S, MD, Nissinen A, MD, PhD and Kromhout D, $\mathrm{PhD}$. Physical activity in relation to cognitive decline in elderly men. Neurology, 2004 December 28; 63(12): 2316-2321.

13. Hayashi D, Gonçalves CG, Parreira RB, Fernandes KB, Teixeira DC, Silva RA, Probst VS. Postural balance and physical activity in daily life (PADL) in physically independent older adults with different levels of aerobic exercise capacity. Arch Gerontol Geriatr., 2012 Sep-Oct; 55(2): 480-5.

https://doi.org/10.1016/j.archger.2012.04.009

14. Yaffe K, MD, Barnes D, MPH, Nevitt M, PhD, Lui Li-Y, MA, MS, Covinsky K, MD. A prospective study of physical activity and cognitive decline in elderly women. Arch Intern Med., 2001; 161(14): 1703-1708. doi:10.1001/archinte.161.14.1703. https://doi.org/10.1001/archinte.161.14.1703

15. Laurin D, MSc, Verreault R, MD, PhD, Lindsay J, PhD, MacPherson K, MD, Rockwood K, MD. Physical activity and risk of cognitive impairment and dementia in elderly persons. Arch Neurol., 2001; 58(3): 498-504. doi:10.1001/archneur.58.3.498. https://doi.org/10.1001/archneur.58.3.498

16. Pang MY, Eng JJ. Muscle strength is a determinant of bone mineral content in the hemiparetic upper extremity: implications for stroke rehabilitation. Bone, 2005; 37:103-11.

https://doi.org/10.1016/j.bone.2005.03.009

17. Perrin PP, Gauchard GC, Perrot C, Jeandel C. Effects of physical and sporting activities on balance control in eldery people. Br J Sports Med 1999; 33:121-6. https://doi.org/10.1136/bjsm.33.2.121

18. Rossiter-Fornoff JE, Wolf SL, Wolfson LI, Buchner DM. A cross-sectional validation study of the FICSIT common data base static balance measures. Frailty and injuries: cooperative studies of intervention techniques. J Gerontol A Biol Sci Med Sci 1995; 50: M291-M297.

https://doi.org/10.1093/gerona/50A.6.M291

19. Sanchez Neva j Kirk, McGough L Ellen. Physical exercise and cognitive performance in elderly: current perspectives. Clinical Interventions in Ageing 2014; 9: 51-62.

20. Sernache de FreitasI ERF, RogérioII FRPG, YamacitaII CM, VareschiIV Ml, Alexandre da Silva R. Does usual practice of physical activity affect balance in elderly women? Fisioter. mov., 2013; 26(4).

21. Skelton DA. Effects of physical activity on postural stability. Age and Ageing, 2001; 30-S4: 33-39.

22. Skurvydas A. Judesių mokslas: raumenys, valdymas, mokymas, reabilitavimas, sveikatinimas, treniravimas, metodologija. Kaunas. LKKA, 2008.

23. Šiupšinskas L. Fizinio aktyvumo poveikis žmogaus organizmo sandarai, funkcijoms bei lètinių neinfekcinių ligų pasireiškimui. Kaunas, Vitae Litera, 2008.

24. Wolfe RR. The underappreciated role of muscle in health and disease. Am J Clin Nutr 2006; 84:475-82. 
THE EXPRESSION AND RELATIONSHIPS BETWEEN PHYSICAL AND COGNITIVE CAPACITIES INFLUENCING THE FALLS RISK OF ELDERLY PERSONS

V. Piščalkienė, J. Knašienė, E. Lapinskas R. Rutkauskienè, I. Knyvienè

Key words: the elderly and older persons, evaluation of the static and dynamic balance, falls, assessment of the mental (cognitive) performance (MMSE), physical activity.

The aim of the research: to assess the falls occurring among the old and elderly persons influencing their physical and cognitive expression and relationships.

Research methods: analysis of the scientific literature, tests (grip strength measurement, dynamic balance assessment, "The timed Up and Go" test, static balance assessment by the modified "Romberg test"and the machine "Sigma Balance PAD", body height and body weight measurements, mental performance evaluation by the MMSE test, oral interviews (surveys), statistical data analysis using SPSS 17 (descriptive statistics, T test, Anova test, correlation analysis).

Persons targeted at the research: The study involved 65 people whose average age was 74.3 years. Minimum age - 60 years, maximum,- 86 years. The subjects were divided according to age groups: $60-74$ years $(41.3 \%)$ and 75 years or more $(58.7 \%)$ persons

Results: The results of the Romberg test tended to worsen in the face of the complexity of the task requirements. The subjects succeeded to better perform the Romberg test with their eyes open than closed. The task "The timed up and go" test took the average time $-15.9 \mathrm{sec}$. The minimum mental activity test (MMSE) showed that more than $2 / 3$ of the elderly and old persons had normal cognitive functioning, and the rest had smaller or larger problems regarding these functions.

In assessing the power of a standard hand dynamometer it was found that the right and left-hand averaged $24 \mathrm{~kg}$. The left upper arm thickness is $31.9 \mathrm{~cm}$, the right $32.5 \mathrm{~cm}$ The left calf thickness $-38.3 \mathrm{~cm}$, the right $-38.2 \mathrm{~cm}$. The static balance was measured using "Sigma Balance Pad". However, this device did not evaluate the balance of all test persons but only of to those who on their own managed to stand on an unstable platform. The length of the visual field was $12.6 \mathrm{~cm}$, and the size of the visual area was $0.46 \mathrm{~cm}^{2}$.

The average, and in some cases, a strong statistical deviation between the right and left hand grip strength, was measured on the dynamometer, and static and dynamic balance,calf thickness, and even cognitive functions were evaluated by MMSE. Evaluating the statistical balance, relevant differences appeared which show that the lengt of the visual field at the time of measuring is connected with the size of the visual area (strong correlation). Also, the visual length is statistically significantly associated with the subjects' calf thickness (weak statistical relationship). It was found that individuals who currently live a physically active life have better dynamic balance indicators and better mental capacities (status?). Individuals with signs of malnutrition whose body mass index (BMI) is lower than the norm show weaker MMSE results. These conclusions are statistically significant $(\mathrm{p} \leq 0.05)$.

The persons who participated in the study and who over the past six months have not experienced any falls, had a stronger left and right grip strenght $(\mathrm{p} \leq 0.05)$. The task "The timed up and go"test was more quickly performed by the group of inexperienced persons $(\mathrm{p} \leq 0.05)$. The group of individuals who did not experience fallings had improved static balance indicators $(\mathrm{p} \leq 0.05)$. Individuals who are physically more active (they practice walking, working in the garden, and so on) are less likely to experience fallings ( $\mathrm{p} \leq 0.05)$.

Correspondence to: viktorija.piscalkiene@go.kauko.lt

Gauta 2016-11-15 